\title{
PubliczNopraWNe MECHANIZMY STYMULOWANIA KONKURENCYJNOŚCI W PROJEKTACH EUROPEJSKICH
}

\section{Wstęp}

Problematyka wydatkowania publicznych środków finansowych została szeroko opisana $\mathrm{w}$ literaturze przedmiotu. Piśmiennictwo, co prawda, poświęca więcej uwagi sferze dochodowej podmiotów gospodarujących niż wydatkowej, co zdaje się być rezultatem dominującej współcześnie doktryny neoliberalnej - stanowiącej ciągle mainstream w myśli ekonomicznej Unii Europejskiej (zarówno na poziomie państw członkowskich jak i na poziomie samej organizacji) - nie oznacza to jednak zupełnej kapitulacji podejścia wydatkowego. Zwłaszcza, gdy empiria dotyczy tak żywotnego zagadnienia dla funkcjonowania gospodarek narodowych i ponadnarodowych jak finanse publiczne ${ }^{1}$.

Dnia 1 maja 2004 r., czyli z chwilą przystąpienia Polski do struktur Unii Europejskiej (UE) otworzyła się przed naszym krajem możliwość absorpcji zewnętrznych źródeł finansowania dla wszelkiego rodzaju zakupów i przedsięwzięć inwestycyjnych, z przeznaczeniem na wyrównywanie różnic rozwojowych w aspekcie społeczno-gospodarczym, dzielących Polskę od krajów „Starej 15”. Dodatkowy napływ kapitału do rodzimej gospodarki w postaci instrumentów finansowych polityk UE, w rodza-

* Dr, Uniwersytet Pedagogiczny im. Komisji Edukacji Narodowej w Krakowie; e-mail: marcin.kepa@lexeconomica.eu.

1 Przez „finanse publiczne" rozumie się tu szeroko: środki finansowe ujęte w budżecie Unii Europejskiej (na temat budżetu UE, zob. A. Wernik, Finanse publiczne. Cele, struktury, uwarunkowania, Warszawa 2011, s. 185 i nast.) i „środki finansowe” w rozumieniu art. 5 ustawy z dnia 27 sierpnia 2009 r. o finansach publicznych, tekst jednolity: Dz. U. z 2019 r. poz. $869,1622,1649,2020$ (dalej: u.f.p.). 
ju funduszy strukturalnych (Structural Funds)2, znacznie zdynamizował rozwój rynków w Polsce, w tym segment zamówień publicznych. Polska uzyskała status kraju kohezyjnego, który zachowuje do dzisiaj. Nieodzownym stało się stworzenie, a później modyfikowanie w reakcji na zmieniające się czynniki egzo- i endogeniczne, mechanizmu stymulowania konkurencyjności ${ }^{3}$ przy wydatkowaniu transferów pieniężnych pochodzących z budżetu UE, zwłaszcza przez sektor prywatny. Mechanizm ten zasadza się na meta zasadach publicznego prawa gospodarczego i prawa finansowego: zasadzie racjonalności, efektywności i konkurencyjności.

Celem pracy jest ukazanie genezy i ewolucji oraz przedstawienie wstępnej oceny mechanizmów stymulowania konkurencyjności w projektach europejskich tworzonych przez organy administracji publicznej ${ }^{4}$, odpowiadające za sprawną i efektywną dystrybucję środków unijnych na poziomie krajowym. Na treść pracy składać się będą zarówno uwagi teoretycznoprawne, jak i te związane z praktyką funkcjonowania badanych przepisów prawa w wybranym obszarze gospodarki.

Czyniąc zadość stronie metodologicznej opracowania, należy wyraźnie rozróżnić podmiot i przedmiot badań oraz zakres temporalny analizy prawnej.

Podmiotem analizy są beneficjenci środków finansowych pochodzących z Europejskiego Funduszu Społecznego (EFS) ${ }^{5}$, pozyskanych w ra-

2 Fundusze tworzone bezpośrednio w budżecie UE: Europejski Fundusz Rozwoju Regionalnego, Europejski Fundusz Społeczny i Fundusz Spójności.

3 Wbrew powierzchownej opinii, „konkurencyjność” nie jest synonimem „konkurencji”. „Konkurencja” - w ujęciu prawnym - to głównie prawo antymonopolowe (ustawa z dnia 16 lutego 2007 r. o ochronie konkurencji i konsumentów, tekst jednolity: Dz. U. z 2019 r. poz. 369, 1571, 1667) i przepisy związane ze zwalczaniem nieuczciwej konkurencji (ustawa z dnia 16 kwietnia 1993 r. o zwalczaniu nieuczciwej konkurencji, tekst jednolity: Dz. U. z 2019 r. poz. 1010, 1649). „Konkurencyjność” ma wiele znaczeń, m.in. jest to zdolność podmiotów gospodarujących do uzyskania możliwie wysokiej stopy zwrotu od zastosowanych czynników produkcji. Konkurencyjność ujawnia się najpełniej w warunkach uczciwej konkurencji. W projektach europejskich „konkurencyjność” stała się jednym z wiodących zagadnień związanych z próbą urynkowienia zakupów dokonywanych w ramach tychże przedsięwzięć - konkurencja o zamówienie (kontrakty).

4 Celowo pomija się w artykule szczegółową analizę prawa powszechnie obowiązującego dotyczącą projektów europejskich (na poziomie unijnym i krajowym) - z uwagi na szeroką literaturę, a skupia się głównie na twórczej działalności organów administracji publicznej.

5 Prawo UE ustalające główne cele, rodzaje działalności i oczekiwane rezultaty funduszu, to rozporządzenie Parlamentu Europejskiego i Rady (UE) nr 1304/2013 z dnia 
mach finansowania tzw. projektów „miękkich”, czyli najogólniej mówiąc, projektów, w ramach których nie wytwarzano lub dostarczano rzeczy materialnych lub działalność ta miała charakter uboczny (nie stanowiła celu głównego projektu). W okresie programowania budżetu UE ustalonym na lata 2007-2013 wiodącym krajowym narzędziem koordynującym politykę finansową w obszarach „miękkich”, był Program Operacyjny Kapitał Ludzki (PO KL) ${ }^{6}$. Obecnie, w okresie programowania budżetu UE 20142020, środki z Europejskiego Funduszu Społecznego są wykorzystywane na dwóch poziomach: krajowym i regionalnym. Na poziomie krajowym funkcjonuje jeden Program Operacyjny - Wiedza Edukacja Rozwój, który otrzymał 4, 4 mld euro, co stanowi ok. 34\% ogółu środków. Pozostałe ponad 66\% rozdzielono między 16 programów regionalnych. Taka decentralizacja zarządzania ma na celu przybliżenie decyzji o finansowaniu projektów do ich głównych odbiorców, tak by jak najlepiej zaspokoić potrzeby regionów i ich społeczności ${ }^{7}$.

Natomiast przedmiot analizy to określony przez państwo zespół norm prawnych i administracyjnych ${ }^{8}$, przy użyciu których zobowiązuje się beneficjentów do dokonywania zakupów publicznych w ramach projektów europejskich ${ }^{9}$. Przy czym treść regulacji prawnych i administracyjnych,

17 grudnia 2013 r. w sprawie Europejskiego Funduszu Społecznego i uchylające rozporządzenie Rady (WE) nr 1081/2006, Dz. Urz. UE L 347 z 20.12 2013, s. 470-486.

6 Program Operacyjny Kapitał Ludzki, został zaakceptowany przez Radę Ministrów w dniu 7 września 2007 r. i zatwierdzono go decyzją Komisji Europejskiej z dnia 28 września 2007 r., nr K(2007)4547, z uwzględnieniem zmian zatwierdzonych przez Komisję Europejską. Oficjalnie PO KL został przekazany do Komisji Europejskiej w dniu 12 grudnia 2006 r. Z uwagi na ogólny charakter programów operacyjnych kierowanych do Komisji Europejskiej, każda instytucja zarządzająca programem operacyjnym przygotowała dodatkowy dokument precyzujący jego postanowienia. W przypadku PO KL był to Szczegółowy Opis Priorytetów Programu Operacyjnego Kapitał Ludzki. Obowiązek przygotowania tego dokumentu spoczywał na instytucji zarządzającej programem operacyjnym.

7 Portal Funduszy Europejskich, http://www.funduszeeuropejskie.gov.pl [dostęp: 8.12.2017 r.].

8 Głównie dokumenty rządowe (wytyczne, interpretacje i zalecenia), które nie stanowią prawa powszechnie obowiązującego, a beneficjentów projektów europejskich zobowiązuje się do ich stosowania i przestrzegania, na podstawie przyjętej adhezyjnie umowy o dofinansowanie projektu europejskiego, która stanowi warunek przyznania pomocy finansowej.

9 Przez pojęcie „projekty europejskie” rozumie się realizację takich projektów, które są współfinansowane z budżetu Unii Europejskiej za pomocą przewidzianych w prawie UE instrumentów finansowych, np. EFS. 
stanowi emanację prawa UE w tym zakresie. Co do statusu beneficjentów, należy wprowadzić jeszcze jedno słowo uściślenia. Szczególna uwaga, zostanie zwrócona na podmioty sektora prywatnego ${ }^{10}$ wydatkujące publiczne środki finansowe $\mathrm{w}$ ramach dofinansowania projektów europejskich, albowiem $\mathrm{w}$ przypadku podmiotów sektora publicznego tę sprawę - co do zasady - uregulowano na poziomie ustaw, m.in. w prawie o finansach publicznych (art. 44 u.f.p.) oraz w ustawie z dnia 29 stycznia 2004 r. Prawo zamówień publicznych ${ }^{11}$ - przy wydatkowaniu środków powyżej progu bagatelności ${ }^{12}$ (art. 4 pkt 8 u.p.z.p.).

Ramy czasowe objęte badaniem to dwa okresy programowania budżetu UE: lata 2007-2013 i lata 2014-2020. Szczególny nacisk zostanie położony na publicznoprawne (administracyjno-prawne) metody wydatkowania środków finansowych z EFS w ramach projektów europejskich.

10 Jak wskazuje J.E. Stiglitz: „granice między instytucjami publicznymi i prywatnymi są często bardzo płynne", J.E. Stiglitz, Ekonomia sektora publicznego, przekł. R. Rapacki i in., Warszawa 2004, s. 15. Linia demarkacyjna przy rozróżnieniu sektora prywatnego i publicznego w pracy została określona przez stronę rządową, która dla badań statystycznych projektów europejskich narzuciła własną strukturę klasyfikacji beneficjentów według głównych kategorii form prawnych. Zatem przez sektor prywatny w pracy rozumie się nie tylko przedsiębiorców prywatnych, ale także instytucje typu non-profit, ponieważ system wydatkowania środków przyznawanych w ramach dofinansowania projektów europejskich dla obu grup podmiotów został ustalony w ten sam sposób i pełni swoiste kryterium rozróżnienia. Określenie jest umowne i wprowadzone do pracy tylko dla uproszczenia logiki dalszych wywodów, ponieważ w gospodarce rynkowej instytucje non-profit tworzą tzw. trzeci sektor - "pozarządowy” (obok publicznego i prywatnego). Na temat organizacji non-profit i ich roli we współczesnej gospodarce rynkowej, zob. A. Politaj [w:] M. Brol (red.), Zarys ekonomii sektora publicznego, Wrocław 2010, s. 191 i nast.

11 Ustawa z dnia 29 stycznia 2004 r. Prawo zamówień publicznych, tekst jednolity: Dz. U. z 2019 r. poz. 1843 z późn. zm. (dalej: u.p.z.p.).

12 Próg bagatelności ustala się na podstawie administracyjno-prawnego kursu z rozporządzenia Prezesa Rady Ministrów wydawanego na podstawie delegacji z art. 11 ust. 8 u.p.z.p.: „Prezes Rady Ministrów określi, w drodze rozporządzenia, kwoty wartości zamówień oraz konkursów, od których jest uzależniony obowiązek przekazywania ogłoszeń Urzędowi Oficjalnych Publikacji Wspólnot Europejskich, mając na względzie obowiązujące w tym zakresie przepisy prawa Unii Europejskiej". Aktualnie kurs ten wynosi 4,1749. Z ekonomicznego punktu widzenia jest to „kurs sztywny". 


\section{1. Środki finansowe z EFS i ogólne zasady ich wydatkowania}

Ścieżka alokacji środków finansowych pochodzących z Europejskiego Funduszu Społecznego na poziom krajowy, rysuje się w sposób następujący. Środki finansowe z EFS przekazywane przez Komisję Europejską (KE) jako zaliczki, płatności okresowe oraz płatność salda końcowego wpływają na wyodrębniony rachunek bankowy prowadzony przez Ministra Rozwoju i Finansów (MRiF) w euro, a następnie po ich przewalutowaniu, przekazywane są na podstawie dyspozycji MRiF na rachunek dochodów budżetu środków europejskich (na poziomie krajowym MRiF jest właściwą instytucją dla otrzymywania płatności dokonywanych przez KE). Kolejno, środki te przesuwa się z budżetu środków europejskich - gdzie są zgrupowane, wydzielone i wykazane w budżecie państwa - na finansowanie poszczególnych programów. W danym roku budżetowym, ujęte są w budżecie środków europejskich ${ }^{13}$ i budżecie środków krajowych (współfinansowanie krajowe) ${ }^{14}$. Ostatecznie środki te trafiają do beneficjentów i wypłacane są przez instytucje zarządzające, na podstawie zatwierdzonych uprzednio wniosków o płatność, składanych zgodnie z zatwierdzonym ex ante harmonogramem projektu.

Pierwotnie procedurę wydatkowania środków unijnych przez beneficjentów z sektora prywatnego uregulowano w u.p.z.p. Legislator zastępując poprzednią ustawę zamówieniową (ustawa z dnia 10 czerwca $1994 \mathrm{r}$. o zamówieniach publicznych ${ }^{15}$ ) wersją dostosowaną do prawa UE $w$ tym zakresie, zdecydował się pozostawić w gestii instytucji wdrażającej lub instytucji zarządzającej, instrument prawny umożliwiający zobligowanie beneficjenta środków finansowych pochodzących z budżetu UE do stosowania przepisów właściwych dla zamówień publicznych. Tym samym

13 „Budżet środków europejskich" to roczny plan dochodów i podlegających refundacji wydatków przeznaczonych na realizację programów finansowanych z udziałem środków europejskich, z wyłączeniem wydatków na finansowanie projektów pomocy technicznej. W budżecie środków europejskich są ujmowane dochody z tytułu realizacji programów finansowanych z udziałem środków europejskich oraz wydatki na realizację tych programów w części podlegającej refundacji.

${ }^{14} \mathrm{~W}$ „budżecie środków krajowych” planowane są wydatki na współfinansowanie projektów europejskich w ramach komponentu regionalnego oraz komponentu centralnego.

15 Ustawa z dnia 10 czerwca 1994 r. o zamówieniach publicznych, Dz. U. z 1994 r. Nr 76, poz. 344 z późn. zm. 
wykorzystując prawną formę działania administracji ${ }^{16}$ - umowę cywilnoprawną - organ administracji publicznej mógł zobowiązać podmioty spoza systemu finansów publicznych do stosowania ustawy zamówieniowej przy ponoszeniu wydatków w ramach projektów europejskich.

Dla zamawiających ad hoc zobowiązanych do stosowania u.p.z.p., decyzja organu reprezentującego państwo, wywoływała określone skutki w systemie struktury organizacyjnej: „powiązanej w określony sposób ze sobą oraz z całością, elementy danej organizacji tworzące stosowny układ"17. Po stronie kosztów prowadzenia działalności gospodarczej, dochodził ten, związany z zatrudnieniem wykwalifikowanej kadry pracowniczej, a wiadomości z zakresu zamówień publicznych należą do kategorii wiadomości specjalnych, na które jest zgłaszany nieustający popyt na rynku pracy. Abstrahując od wzrostu kosztów transakcyjnych, pojawił się doniosły problem prawny. Podmioty z sektora prywatnego, funkcjonujące w obrocie gospodarczym na gruncie prawa cywilnego, „wprzęgnięto” w ramy właściwe dla podmiotów z sektora publicznego, czyli w sferę publicznego prawa gospodarczego. W sferze tej, $\mathrm{z}$ racji ochrony interesu publicznego, regulacja stosunków prawnych odbywa się z pozycji imperium. W tym sensie można mówić o powstaniu węzła prawnego wyznaczającego istotę stosunku administracyjno-prawnego, a składającego się wyłącznie z uprawnień i obowiązków zmierzających do konkretyzacji prawa ${ }^{18}$.

Powyższe zniosła nowela ustawy z dnia 2 grudnia 2009 r. o zmianie ustawy - Prawo zamówień publicznych oraz niektórych innych ustaw ${ }^{19}$, uchylając art. 3 ust. 1 pkt 6 u.p.z.p. Na decyzje ustawodawcy, w kwestii odformalizowania postępowania przy wydatkowaniu środków unijnych przez zamawiających spoza systemu finansów publicznych, decydujący wpływ miała, nie sytuacja ekonomiczna beneficjentów i odczuwalny przyrost kosztów transakcyjnych, ale konieczność przyspieszenia wydat-

16 „Przez prawną formę działania administracji należy rozumieć prawnie określony typ konkretnej czynności prawnej. Typ czynności nie zależy od zakresu spraw, w jakich te czynności występują, ani od tego, czy są one powiązane z innymi czynnościami”, M. Wierzbowski, A. Wiktorowska [w:] M. Wierzbowski, J. Jagielski, J. Lang, M. Szubiakowski, A. Wiktorowska (red.), Prawo administracyjne, Warszawa 2008', s. 277.

17 A. Pakuła [w:] A. Chrisidu-Budnik, J. Korczak, A. Pakuła, J. Supernat, Nauka organizacji i zarzadzania, [Wrocław] 2005, s. 313.

18 Zob. T. Kiełkowski, Sprawa administracyjna, Kraków 2004, s. 29.

19 Ustawa z dnia 2 grudnia 2009 r. o zmianie ustawy - Prawo zamówień publicznych oraz niektórych innych ustaw, Dz. U. z 2009 r. Nr 223, poz. 1778. 
kowania środków unijnych. Zrezygnowano z możliwości zobowiązywania podmiotów z sektora prywatnego do stosowania trybów udzielania zamówień publicznych z u.p.z.p. Dotychczasowy mechanizm został zastąpiony bardziej elastycznym sposobem wydatkowania, a oparto go na zasadzie równego traktowania, uczciwej konkurencji oraz przejrzystości.

Stan aktualny ukształtował się w ten sposób, że podmioty z sektora prywatnego - funkcjonujące na gruncie stosunków cywilnoprawnych w przeciwieństwie do podmiotów publicznych (zwanych w nauce administracji także ",administrującymi" ${ }^{20}$ ), nie są zobowiązane przy ponoszeniu wydatków na zakup towarów, usług i robót budowlanych w ramach projektów europejskich współfinansowanych z EFS, stosować tryby udzielania zamówień publicznych określone u.p.z.p. Stosują się do administracyjno-prawnych mechanizmów stymulowania konkurencyjności ustalanych a priori przez naczelny organ administracji państwowej (rządowej) lub inny prawnie upoważniony ośrodek decyzyjny, będący dysponentem środków unijnych. Właściwy minister, bo o tej funkcji tutaj mowa, to w nauce administracji naczelny organ administracji państwowej, którego w doktrynie wyróżnia się po następujących cechach:

[...] powoływany przez Prezydenta albo po uprzednim wyborze przez sejm, organ zwierzchni wobec pozostałych organów w strukturze administracji rządowej,

właściwość terytorialna obejmuje obszar całego kraju, odpowiedzialność polityczna i konstytucyjna ${ }^{21}$.

Warto w tym miejscu zaznaczyć, że w poprzednim okresie programowania budżetu UE, tj. w latach 2007-2013, ustawa z dnia 6 grudnia 2006 r. o zasadach prowadzenia polityki rozwoju ${ }^{22}$, nie przewidywała expressis verbis delegacji ustawowej do wydania rozporządzenia dla naczelnego organu administracji państwowej w zakresie kształtowania polityki w zakresie kwalifikowalności wydatków w ramach projektów europejskich. Zakres materialnoprawny ww. aktu prawnego wprowadził za to pojęcie prawne „kwalifikowalność wydatków" (art. 5 pkt 6 u.p.p.r.), rozumiane jako:

20 "Podmioty administrujące” to pojęcie szersze niż „podmioty administracji publicznej”. Na temat pojęcia „organ administrujący” (wg J. Bocia), zob. J. Boć (red.), Prawo administracyjne, Wrocław 2007, s. 132.

21 E. Knosala, L. Zacharko, A. Matan, Elementy nauki administracji, Wrocław 2002, s. 20.

22 Ustawa z dnia 6 grudnia 2006 r. o zasadach prowadzenia polityki rozwoju, tekst jednolity: Dz. U. z 2019 r. poz. 1295, 2020 (dalej: u.p.p.r.). 
spełnienie przez wydatki poniesione $\mathrm{w}$ ramach programów operacyjnych kryteriów:

a) spójności z postanowieniami przyjętego programu operacyjnego,

b) określonych szczegółowo przez instytucję zarządzającą zgodnie z art. 26 ust. 1 pkt 6 [ u.p.p.r. - M.K.],

c) dodatkowych, przewidzianych dla danego źródła finansowania, w przypadku programów finansowanych ze źródeł zagranicznych.

Ustalono także przykładowy katalog zadań instytucji zarządzającej, w ramach której przewidziano określenie kryteriów kwalifikowalności wydatków objętych dofinansowaniem w ramach programu operacyjnego (art. 26 ust. 1 pkt 6 u.p.p.r.). Przy czym, za instytucję zarządzającą w rozumieniu u.p.p.r. (art. 25 ust. 2) przyjęto:

1) w przypadku krajowego programu operacyjnego - odpowiednio właściwy minister albo minister właściwy do spraw rozwoju regionalnego, zgodnie $\mathrm{z}$ art. 18 [u.p.p.r. - M.K.];

2) w przypadku regionalnego programu operacyjnego - zarząd województwa.

Tymczasem w ustawie dotyczącej okresu programowania budżetu UE 2014-2020, ustawodawca poszedł krok dalej. W ustawie z dnia 11 lipca 2014 r. o zasadach realizacji programów w zakresie polityki spójności finansowanych $\mathrm{w}$ perspektywie finansowej 2014-202023 upoważnił ministra właściwego do spraw rozwoju regionalnego wykonującego zadania państwa członkowskiego, w celu zapewnienia zgodności sposobu realizacji programów operacyjnych z prawem Unii Europejskiej w zakresie wdrażania funduszy strukturalnych i Funduszu Spójności oraz spełniania wymagań określanych przez Komisję Europejską w tym zakresie, a także w celu zapewnienia jednolitości sposobu realizacji programów operacyjnych i prawidłowości realizacji zadań i obowiązków określonych ustawą, do wydawania wytycznych dotyczących m.in. kwalifikowalności wydatków w ramach programów operacyjnych (art. 5 ust. 1 pkt 5 u.p.p.p.s.). Wyraźnie wyznaczył tym samym pole do działania w formie aktu administracyjnego dla właściwego ministra. Jednak uwagę zwraca pewna niekonsekwencja ustawodawcy. Stworzono bowiem swoistą „protezę praw-

23 Ustawa z dnia 11 lipca 2014 r. o zasadach realizacji programów w zakresie polityki spójności finansowanych w perspektywie finansowej 2014-2020, tekst jednolity: Dz. U. z 2018 r. poz. 1431, 1544, z 2019 r. poz. 60, 730, 572, 2020 (dalej: u.p.p.p.s.). 
ną", czyli wytyczne naczelnego organu administracji państwowej, które i tak nie zyskują statusu prawa powszechnie obowiązującego; vide art. 87 ust. 1 i 2 Konstytucji RP24. Wprowadzenie upoważnienia do wydawania rozporządzeń w zakresie procedury, określającej mechanizmy stymulowania konkurencyjności $\mathrm{w}$ projektach europejskich $\mathrm{w}$ ramach kwalifikowalności wydatków przez wyznaczony w ustawie naczelny organ administracji państwowej, uczyniłoby bezprzedmiotowym zobowiązywanie beneficjentów do stosowania wytycznych, na gruncie stosunków cywilnoprawnych. Trudno uciec od przekonania, że ustawodawca zatrzymał się $\mathrm{w}$ połowie drogi.

\section{Mechanizmy stymulowania konkurencyjności w projektach europejskich w latach 2007-2013}

Ewolucja koncepcji wydatkowania środków finansowych pochodzących $\mathrm{z}$ budżet UE $\mathrm{w}$ ramach projektów europejskich i towarzyszącego im współfinansowania ze środków krajowych, charakteryzuje się dużą amplitudą zmian. Od w pełni sformalizowanej, wyrastającej z omnipotencji państwa skłonnego regulować każdy niemal przejaw życia gospodarczego, którego przedmiot stanowi obrót środkami publicznymi, do koncepcji nieco bardziej liberalnej, strukturalnie i organizacyjnie odformalizowanej.

W badanym okresie programowania budżetu UE, mechanizmy stymulowania konkurencyjności w projektach europejskich ustalał właściwy minister, przy użyciu instrumentu prawnego pod nazwą: wytycznych (Krajowe wytyczne dotyczące kwalifikowania wydatków w ramach funduszy strukturalnych i Funduszu Spójności w okresie programowania 2007-2013). Na potrzeby pracy, dla okresu programowania budżetu UE 2007-2013 używamy ogólnej nazwy, ukształtowanej w praktyce: Wytyczne w zakresie kwalifikowania wydatków w ramach PO KL. Dokument rządowy, a z punktu widzenia nauki prawa administracyjnego "akt administracyjny generalny" o charakterze ogólnym i władczym²5, był aktualizowany dziesięć

${ }^{24}$ Konstytucja Rzeczypospolitej Polskiej z dnia 2 kwietnia 1997 r., Dz. U. z 1997 r. Nr 78, poz. 483 z późn. zm.

25 Przez „akt administracyjny generalny” rozumiem, za W. Chróścielewskim: „wydany przez organ administracji publicznej w znaczeniu ustrojowym lub funkcjonalnym, 
razy. Rzeczony akt administracyjny był i jest typowym narzędziem realizacji polityki administracyjnej na szczeblu centralnym. Podobnym fluktuacjom co sam akt, podlegał także organ administracyjny, który go wydawał. Wraz z przekształceniami ustrojowo-kompetencyjnymi zmieniał częściowo właściwość rzeczową. W początkowym okresie programowania budżetu UE, tj. w latach 2007-2013, ministrem właściwym był Minister Rozwoju Regionalnego, a następnie Minister Infrastruktury i Rozwoju.

W pierwszych Wytycznych w zakresie kwalifikowania wydatków w ramach $P O K L^{26}$, ukształtowano pogląd, że:

1) Co do zasady wszystkie wydatki $w$ ramach PO KL są kwalifikowalne, o ile:

a) są niezbędne dla realizacji projektu, a więc mają bezpośredni związek $\mathrm{z}$ celami projektu;

b) są efektywne tj. spełniają wymogi efektywnego zarządzania finansami (relacja nakład/rezultat);

c) zostały faktycznie poniesione;

d) są udokumentowane;

e) zostały przewidziane $\mathrm{w}$ zatwierdzonym budżecie projektu zgodnie z zasadami w zakresie konstruowania budżetu w ramach PO KL;

f) są zgodne ze szczegółowymi zasadami określonymi w niniejszych Wytycznych tj:

i. nie zostały wymienione $\mathrm{w}$ katalogu wydatków niekwalifikowalnych z EFS $\mathrm{w}$ podrozdziale 4.1;

na podstawie przepisów prawa, akt o charakterze ogólnym i władczym, który zawiera w swojej treści nowe normy prawne lub dokonuje interpretacji norm już wcześniej ustanowionych, a niekiedy zawiera jedynie urzędowe informacje rzutujące na proces stosowania prawa. Akt ten najczęściej będzie aktem abstrakcyjnym, nie konsumującym się poprzez jednorazowe zastosowanie [...]", J. Chróścielewski, Akt administracyjny generalny, Łódź 1994, s. 105. W zaprezentowanym tu znaczeniu, omawiane wytyczne, stanowią akt administracyjny generalny, albowiem są: 1) wydane przez organ administracji publicznej; 2) na podstawie i w granicach prawa; 3) posiadają charakter ogólny (abstrakcyjny) - nie jest stypizowany wprost krąg odbiorców - i nie konsumują się (nie wygasa) poprzez jednorazowe zastosowanie; 4) wyznaczają zakres praw i obowiązków stron przy wypełnieniu się stanu faktycznego określonego w normie prawnej; 5) tworzą pomiędzy organem administracyjnym a adresatem normy stosunek administracyjno-prawny.

26 Minister Rozwoju Regionalnego, Narodowe Strategiczne Ramy Odniesienia 2007-2013. Wytyczne w zakresie kwalifikowania wydatków w ramach Programu Operacyjnego Kapitat Ludzki, Warszawa, 9 lipca 2007 r., MRR/KL/1.1/07/2007, http:/ / www.kapitalludzki.gov.pl/dokumenty/wytyczne-mrr/wytyczne-kwalifikowalnosc/ [dostęp: 11.07.2019 r.] (dalej: wytyczne w zakresie kwalifikowania wydatków w ramach PO KL - wersja obowiązująca od 9.07.2007 r. do 9.03.2008 r.). 
ii. zostały poniesione zgodnie z zasadami określonymi w niniejszych Wytycznych.

g) są zgodne z odrębnymi przepisami prawa krajowego i wspólnotowego, w szczególności z ustawą z dnia 29 stycznia 2004 r. - Prawo zamówień publicznych ${ }^{27}$.

W kolejnych czterech wersjach Wytycznych w zakresie kwalifikowania wydatków w ramach PO KL właściwie nie zmieniono zasad wydatkowania środków europejskich w EFS - pozostawiono zasady ogólne. Dziwi natomiast fakt, że od dnia 29 stycznia 2010 r., czyli od dnia wejścia w życie nowelizacji u.p.z.p. ${ }^{28}$, do wydania Wytycznych w zakresie kwalifikowania wydatków w ramach PO KL określających zasady wydatkowania środków przyznanych w ramach projektów europejskich, nie określono mechanizmu wydatkowego dla sektora prywatnego. Dziwi to tym bardziej, że wytyczne to - jak ustaliliśmy - akt administracyjny generalny opracowywany i wydawany na poziomie jednego z działów administracji publicznej. W konsekwencji do dnia 1 stycznia 2011 r. powstała pewna luka prawna, a właściwie stan niepewności prawnej w zakresie zasad wydatkowania środków pieniężnych pochodzących z EFS. Środki zaradcze wdrożono w Wytycznych w zakresie kwalifikowania wydatków w ramach PO KL w wersji z dnia 22 listopada 2010 r. ${ }^{29}$ To wtedy napotykamy na pierwszą wersję mechanizmów stymulujących konkurencyjność w projektach europejskich: Przejrzystość $i$ konkurencyjność wydatków oraz Zasadę efektywnego zarzadzania finansami. Ze pewnymi zmianami, ukształtowały one procedurę, z której korzysta sektor prywatny w bieżącym okresie programowania budżetu UE 2014-2020, wydatkując środki przyznane w ramach wniosków o dofinansowanie projektów.

27 Rozdz. 3 podrozdz. 1 pkt 1 wytycznych w zakresie kwalifikowania wydatków w ramach PO KL - wersja obowiązująca od 9.07.2007 r. do 9.03.2008 r.

28 Ustawa z dnia 2 grudnia 2009 r. o zmianie ustawy - Prawo zamówień publicznych oraz niektórych innych ustaw, Dz. U. z 2009 r. Nr 223, poz. 1778.

29 Minister Rozwoju Regionalnego, Narodowe Strategiczne Ramy Odniesienia 2007-2013. Wytyczne w zakresie kwalifikowania wydatków w ramach Programu Operacyjnego Kapitat Ludzki, Warszawa, 22 listopada 2010 r., MRR/KL/1(6)/11/10, http:/ / www.kapitalludzki.gov.pl/ dokumenty/wytyczne-mrr/wytyczne-kwalifikowalnosc/ [dostęp: 11.07.2019 r.] (dalej: wytyczne w zakresie kwalifikowania wydatków w ramach PO KL - wersja obowiązująca od 1.01.2011 r. do 31.12.2011 r.). 
Powstały wówczas dwie główne zasady wydatkowe, rozumiane jako publicznoprawne mechanizmy stymulujące konkurencyjność w projektach europejskich:

a) „zasada konkurencyjności” - dla zamówień przekraczających wyrażoną $\mathrm{w}$ złotych równowartość kwoty 14 tys. euro netto ${ }^{30}$, oraz

b) "rozeznanie rynku” - w przypadku zakupu usługi lub towaru o wartości powyżej 20 tys. zł netto, ale równocześnie nie przekraczających wyrażonej w złotych równowartości kwoty 14 tys. euro netto.

W uaktualnionej wersji Wytycznych w zakresie kwalifikowania wydatków $w$ ramach $P O K L$ wyraźnie określono, poprzez jakie zachowania beneficjenta podjęte $\mathrm{w}$ toku postępowania $\mathrm{w}$ sprawie zakupu towarów i usług $\mathrm{w}$ ramach projektu, materializować się będzie zasada zachowania uczciwej konkurencji i równego traktowania wykonawców (zasada konkurencyjności) oraz zasada efektywnego i racjonalnego ponoszenia wydatków (rozeznanie rynku) ${ }^{31}$.

Wymienione wyżej zasady ponoszenia wydatków, stanowią emanację polityki unijnej wyrażonej w art. 101-109 Traktatu o funkcjonowaniu Unii Europejskiej (TFUE) ${ }^{32}$. Organy UE ze szczególną pieczołowitością traktują kategorię konkurencyjności. Wszelkie zakłócenia w tej materii poczytywane są, i słusznie, jako zagrożenia dla wzrostu gospodarczego. Do korygowania zachowań antykonkurencyjnych umocowana jest KE, jako organ stojący na straży przepisów gwarantujących swobodną i uczciwą konkurencję na rynku $\mathrm{UE}^{33}$.

„Rozeznanie rynku”, w przeciwieństwie do „zasady konkurencyjności", którą charakteryzowała znacznie bardzie formalna procedura, nie musiało być wyrażane poprzez klasyczne „zapytanie ofertowe”, w ramach którego wybierano ofertę najkorzystniejszą ekonomicznie, na uprzednio określonych zasadach. Zgodnie z treścią Wytycznych w zakresie kwalifikowania wydatków w ramach PO KL w wersji z dnia 22 listopada

30 Próg bagatelności „zasady konkurencyjności” wyraźnie skorelowano z progiem bagatelności z u.p.z.p. (art. 4 pkt 8 u.p.z.p.).

31 Zob. rozdz. 3.1.4 sekcja 4 wytycznych w zakresie kwalifikowania wydatków w ramach PO KL - wersja obowiązująca od 1.01.2011 r. do 31.12.2011 r.

${ }^{32}$ Wersje skonsolidowane Traktatu o Unii Europejskiej i Traktatu o funkcjonowaniu Unii Europejskiej, Dz. Urz. UE C 83 z 30.03.2010, s. 1-388.

33 Priorytety Komisji Europejskiej, https://ec.europa.eu/commission/index_pl [dostęp: 14.12.2017 r.]. 
2010 r., wydatek był kwalifikowalny, jeśli był racjonalny ${ }^{34}$ i efektywny ${ }^{35}$. Przy czym, przesłanki te należy postrzegać jako:

działania skierowane na osiąganie skuteczności (rozumianej jako optymalna relacja między wyznaczonymi celami i zadaniami a osiągniętymi efektami ich realizacji) oraz efektywności (bazującej na oszczędności dysponenta w gospodarowaniu posiadanymi zasobami) ${ }^{36}$.

„Rozeznanie rynku” określono jako „porównanie cen u co najmniej trzech potencjalnych dostawców towarów lub usługodawców, [...] o ile na rynku istnieje trzech potencjalnych wykonawców" ${ }^{\prime 37}$. Pierwotnie nie zastrzeżono wprost formy pisemnej dla „rozeznania rynku” ${ }^{\prime 38}$, a nawet zawiązanej w ten sposób umowy cywilnoprawnej. Jednak w praktyce często się ją napotykało - wedle zasady, że najbardziej wiarygodny, posiadający najwyższą moc dowodową, zwłaszcza dla organów kontrolnych, jest dowód z dokumentów. Od dnia 1 stycznia 2012 r. wprowadzono zasadę pisemności ${ }^{39}$, którą ukształtowały w badanym okresie programowania budżetu UE Wytyczne w zakresie kwalifikowania wydatków w ramach PO KL w wersji z dnia 2 kwietnia 2014 r..$^{40}$ :

34 Na temat rodowodu pojęcia „racjonalności”, zob. K. Adamiecki, Nauka organizacji i jej rola w życiu gospodarczym, Warszawa 1932.

35 „Mierniki efektywności” wg używanej przez OECD metodologii dzielimy na: mierniki produktu, mierniki efektu częściowego i mierniki efektu końcowego. Na temat „mierników efektywności” stosowanych w UE, zob. K. Karpińska [w:] T. Lubińska (red.), Budżet zadaniowy w Polsce. Reorientacja z wydatkowania na zarządzanie pieniędzmi publicznymi, Warszawa 2007, s. 39 i nast.

36 J. Stankiewicz [w:] E. Ruśkowski (red.), System prawa finansowego, t. 2. Prawo finansowe sektora finansów publicznych, Warszawa 2010, s. 270, 271.

37 Rozdz. 3 sekcja 4 pkt 3 wytycznych w zakresie kwalifikowania wydatków w ramach PO KL - wersja obowiązująca od 1.01.2011 r. do 31.12.2011 r. Tak ukształtowana zasada rozeznania rynku przetrwała do końca okresu kwalifikowania wydatków w ramach PO KL, tj. 31 grudnia 2015 r.

38 Zob. rozdz. 3 sekcja 4 pkt 6 wytycznych w zakresie kwalifikowania wydatków w ramach PO KL - wersja obowiązująca od 1.01.2011 r. do 31.12.2011 r.

39 Zob. rozdz. 3 sekcja 4 pkt 6, Minister Rozwoju Regionalnego, Narodowe Strategiczne Ramy Odniesienia 2007-2013. Wytyczne w zakresie kwalifikowania wydatków w ramach Programu Operacyjnego Kapitat Ludzki, Warszawa, 15 grudnia 2011 r. MRR/KL/1(7)/12/11, http:/ / www.kapitalludzki.gov.pl/dokumenty/wytyczne-mrr/wytyczne-kwalifikowalnosc/ [dostęp: 14.08.2019 r.] (dalej: wytyczne w zakresie kwalifikowania wydatków w ramach PO KL - wersja obowiązująca od 1.01.2012 r. do 31.08.2012 r.).

40 Minister Infrastruktury i Rozwoju, Narodowe Strategiczne Ramy Odniesienia 20072013. Wytyczne w zakresie kwalifikowania wydatków w ramach Programu Operacyjnego Kapitat 
[...] Udokumentowanie przebiegu procesu rozeznania rynku wymaga formy pisemnej i polega na zarchiwizowaniu np. wydruków stron internetowych z opisem towaru lub usługi i ceną lub wydruków maili z informacją na temat ceny za określony towar lub usługę, albo innego dokumentu. Nie jest wystarczające sporządzenie notatki roboczej lub protokołu z przeprowadzenia rozeznania rynku dokonanego $\mathrm{w}$ drodze wywiadu osobistego lub telefonicznego, chyba że notatka lub protokół potwierdzone zostałyby podpisem każdego $\mathrm{z}$ wymienionych $\mathrm{w}$ ich treści dostawców lub wykonawców ${ }^{41}$.

Notabene błędnie użyto terminu „forma pisemna”, wskazując dorozumianie na art. 78 § 1 i 2 k.c. ${ }^{42}$, gdy de facto mówić możemy jedynie o „pisemności" - wyrażeniu oświadczenia woli za pomocą dowolnego nośnika treści, poprzez dowolny zapis, tak aby druga strona transakcji mogła się z tym oświadczeniem zapoznać i odczytać go.

"Zasada konkurencyjności”, jak już wyartykułowano wyżej, dotyczyła wszystkich zamówień objętych projektem europejskim, które przekraczały wyrażoną w złotych równowartość kwoty 14 tys. euro (bez podatku od towarów i usług $)^{43}$ - wyłączając zamówienia dotyczące zadań wykonywanych przez personel zarządzający projektu oraz zamówienia dotyczące zadań wykonywanych przez personel projektu, z którym beneficjent $\mathrm{w}$ okresie co najmniej jednego roku przed złożeniem wniosku o dofinansowanie projektu współpracował w sposób ciągły lub powtarzalny. Beneficjentów z sektora prywatnego zobowiązano także, aby przy opisie przedmiotu zamówienia, stosowali nazwy i kody CPV (ang. Common Procurement Vocabulary), co było rozwiązaniem logicznym i systemowo spójnym. Na tym etapie rozwoju mechanizmów stymulujących konkurencyjność w projektach europejskich nie tworzono jeszcze zbyt dużej ilości pojęć na potrzeby wytycznych. Inflacja, uwydatniła się z całą mocą w latach następnych. Tak więc, w celu spełnienia „zasady konkurencyjno-

Ludzki, Warszawa, 2 kwietnia 2014 r. MIR/KL/1(1)/04/14, http://www.kapitalludzki. gov.pl/dokumenty/wytyczne-mrr/wytyczne-kwalifikowalnosc/ [dostęp: 11.07.2019 r.] (dalej: wytyczne w zakresie kwalifikowania wydatków w ramach PO KL - wersja obowiązująca od 01.05.2014 r.).

${ }^{41}$ Rozdz. 3.1.4 sekcja 4 pkt 6 wytycznych w zakresie kwalifikowania wydatków w ramach PO KL - wersja obowiązująca od 01.05.2014 r.

42 Ustawa z dnia 23 kwietnia 1964 r. Kodeks cywilny, tekst jednolity: Dz. U. z 2019 r. poz. 1145 (dalej: k.c.).

43 Zasady przeliczania euro na złotówki odbywały się na zasadach przyjętych w u.p.z.p. 
ści" należało wysłać „zapytanie ofertowe”, do co najmniej trzech potencjalnych wykonawców, o ile na rynku istniało trzech potencjalnych wykonawców danego zamówienia; równocześnie beneficjent był zobowiązany do upublicznienia „zapytania ofertowego", co najmniej na swojej stronie internetowej, o ile posiadał taką stronę ${ }^{44}$.

Rzucają się tu w oczy, nieostre terminy administracyjno-prawne, takie jak: „zapytanie ofertowe” i „wykonawca”. Przy braku jednoznacznych wskazań, co do właściwości stosunku prawnego rządzącego „zasadą konkurencyjności", przyjęto $\mathrm{w}$ drodze interpretacji wytycznych dokonywanych sukcesywnie przez organ, że mamy do czynienia z typowym stosunkiem prywatnoprawnym. Z tego wynika, że konstrukcja „zapytania ofertowego" zasadza się na treści art. 66 § 1 k.c. Razi tu zwłaszcza brak odesłań do poszczególnych ustaw, normalizujących siatkę pojęciową, stąd wewnętrzny chaos terminologiczny aktu administracyjnego. Podobnie jest z terminem "potencjalny wykonawca”. Tutaj jest kłopot podwójny, ponieważ ani Kodeks cywilny, ani u.p.z.p., nie znają takiego pojęcia. Wytyczne przewidywały za to instytucję "wykonawcy”, definiując go jako osobę fizyczną, osobę prawną albo jednostkę organizacyjną nieposiadającą osobowości prawnej, która ubiega się o udzielenie zamówienia, złożyła ofertę lub zawarła umowę w sprawie zamówienia. Mowa jest tu zatem o sytuacji ex post, przy czym o "potencjalnym wykonawcy” można mówić wyłącznie w sytuacji ex ante. Ale to tylko drobny szczegół, tytułem przykładu.

Abstrahując na moment od meritum, warto zaznaczyć, że konstrukcja formalnoprawna „zasady konkurencyjności”, zbudowana jest w oparciu o zasady ogólne prawa UE, tj. postanowienia TFUE (m.in. art. 18, art. 28 i nast., art. 49 i nast., art. 56 i nast.) oraz Komunikatu Wyjaśniającego Komisji dotyczącego prawa wspólnotowego obowiązującego w dziedzinie udzielania zamówień, które nie są lub są jedynie częściowo objęte dyrektywami w sprawie zamówień publicznych ${ }^{45}$. Powyższe wynikało z faktu, że każdy wydatek poniesiony na zamówienie w projekcie europejskim dotowanym ze środków publicznych, jest wydatkiem publicznym i wi-

44 Zob. rozdz. 3.1 .3 sekcja 3 podsekcja 1 pkt lit a wytycznych w zakresie kwalifikowania wydatków w ramach PO KL - wersja obowiązująca od 1.01.2011 r. do 31.12. 2011 r.

45 Komunikat Wyjaśniający Komisji dotyczący prawa wspólnotowego obowiązującego w dziedzinie udzielania zamówień, które nie są lub są jedynie częściowo objęte dyrektywami w sprawie zamówień publicznych, Dz. Urz. UE C 179 z 1.08.2006, s. 2-7. 
nien podlegać prawu publicznemu - jeśli nie na poziomie prawa kraju członkowskiego, to przynajmniej na poziomie prawa UE.

Idąc dalej, „zapytanie ofertowe” powinno zawierać w szczególności opis przedmiotu zamówienia, kryteria oceny oferty, informację o wagach punktowych lub procentowych przypisanych do poszczególnych kryteriów oceny oferty, sposobu przyznawania punktacji za spełnienie danego kryterium oraz termin składania ofert, przy czym termin na złożenie oferty powinien wynosić nie mniej niż 10 dni roboczych od dnia ogłoszenia zapytania ofertowego ${ }^{46}$.

Analizując konstrukcję „zapytania ofertowego", po pierwsze rzuca się w oczy wymóg zapewnienia transparentności postępowania, w postaci upublicznienia ogłoszenia o wszczęciu postępowania ofertowego. Upublicznienie informacji o możliwości udzielenia zamówienia, tj. zgłaszanie realnego popytu na zakup określonych towarów, usług czy robót budowlanych, powinno dotrzeć do maksymalnej liczby podmiotów rynkowych zdolnych wykonać zamówienie, tak aby uzyskać najkorzystniejszą ekonomicznie ofertę. Tylko wtedy mechanizm rynkowy zadziała bez ograniczeń i uzyskamy faktyczną (rynkową) cenę dobra. Mając to na uwadze, przy konstruowaniu wytycznych należało posłużyć się popularną domeną internetową, np. Biuletynem Zamówień Publicznych ${ }^{47}$ - niestety, stało się inaczej. Brak publikatora zamówień dla sektora prywatnego sprawił, że pojawiła się pokusa ukrycia zamówienia, wywołana "oportunizmem” i tzw. "sekretne zamówienia" - zupełnie jak w początkowych latach obowiązywania ustawy zamówieniowej; tylko tutaj rzecz dotyczyła podmiotów ze sfery prywatnoprawnej - powielono te same błędy. Podmioty gospodarcze, których nie łączyły relacje biznesowe z beneficjentem środków europejskich, nie były w stanie uzyskać informacji o wszczęciu postępowania. Kwestie upublicznienia „zapytania ofertowego" do momentu uruchomienia bazy konkurencyjności - o której w dalszej części pracy zdawała się rekompensować instytucja powiadomienia potencjalnych wykonawców o zamówieniu; jednak i ona nie wytrzymywała krytyki. Nie było gwarancji, że beneficjent wyśle treść zapytania ofertowego do podmiotów, które w jego ocenie złożyć powinny najkorzystniejszą ofer-

46 Zob. rozdz. 3.1 .3 sekcja 3 podsekcja 1 pkt lit. a wytycznych w zakresie kwalifikowania wydatków w ramach PO KL - wersja obowiązująca od 1.01.2011 r. do 31.12. 2011 r.

47 Biuletyn Zamówień Publicznych jest postrzegany jako naturalne miejsce spotkań wykonawców z zamawiającymi. 
tę. Często zdarzało się tak, że beneficjent wysyłał skonstruowane przez siebie zapytanie ofertowe do podmiotów, z którymi pozostawał w relacji biznesowej, oczekując jakiejś formy rewanżu, lub wysyłał je wprost do podmiotów z własnej grupy kapitałowej, działając z nimi w zmowie. Nie przewidziano także zbiorczej informacji publicznej, na okoliczność tego jakie podmioty z sektora prywatnego prowadzą projekty europejskie i realizacji jakich zamówień będą oczekiwały od rynku.

Dopiero w Wytycznych w zakresie kwalifikowania wydatków w ramach PO KL w wersji z dnia 1 lipca $2013 \mathrm{r} .^{48}$ uregulowano tą sprawę. Wprowadzono obowiązek publikacji zamówień na stronie internetowej, która miała powstać niebawem, jednak prace nad jej przygotowaniem trwały na tyle długo, że w zasadzie wymóg ten zaczęto stosować w kolejnej perspektywie budżetowej.

Wracając do zakresu treści „zapytania ofertowego”, konstrukcja ustalona na potrzeby Wytycznych w zakresie kwalifikowania wydatków w ramach PO KL nie budziła już takich zastrzeżeń, jak kwestia dotycząca publikacji ogłoszenia o wszczęciu postępowania ofertowego. Wymóg szczegółowego opisu przedmiotu zamówienia (przy jego ustalaniu posiłkować się należy kodami $C P V$ ), sprecyzowanie kryteriów oceny ofert wraz z określeniem ich wag, sposób punktacji ofert, minimalny termin na złożenie ofert oraz pisemność postępowania (m.in. obowiązek sporządzenia protokołu z wyboru oferty oraz zawarcia umowy w formie pisemnej), były gwarantem nie tylko zakupu towarów lub usług, takich, na jakie zgłasza zapotrzebowanie beneficjent, ale także przeprowadzeniem przejrzystego i uczciwego postępowania - przynajmniej od momentu złożenia ofert. Należy pamiętać, że to beneficjent ustalał treść „zapytania ofertowego”. W tym względzie był związany nie tylko wytycznymi, ale przede wszystkim treścią wniosku o dofinansowanie projektu. Jeśli beneficjent ustanowiłby np. kryteria oceny ofert czy warunki udziału $\mathrm{w}$ postępowaniu niewspółmierne do przedmiotu zamówienia, liczyć by się musiał z nałożeniem korekty finansowej ${ }^{49}$, która byłaby

48 Minister Rozwoju Regionalnego, Narodowe Strategiczne Ramy Odniesienia 2007-2013. Wytyczne w zakresie kwalifikowania wydatków w ramach Programu Operacyjnego Kapitat Ludzki, Warszawa, 1 lipca 2013 r., MRR/KL/1(9)/07/13, http://www.kapitalludzki.gov.pl/dokumenty/wytyczne-mrr/wytyczne-kwalifikowalnosc/ [dostęp: 11.07.2019 r.] (dalej: wytyczne w zakresie kwalifikowania wydatków w ramach PO KL - wersja obowiązująca od 15.07.2013 r. do 30.04.2014 r.).

49 Kwota, o jaką pomniejsza się współfinansowanie UE dla projektu lub programu operacyjnego w związku z nieprawidłowością indywidualną lub systemową - art. 2 pkt 12 
odpowiedzią na zakłócenie konkurencji i nierówne traktowanie wykonawców w ramach jednego postępowania. Tak wiec, dowolność w kształtowaniu treści „,zapytania ofertowego" w dużej mierze ograniczono.

\section{Mechanizmy stymulowania konkurencyjności w projektach europejskich w latach 2014-2020}

W okresie programowania budżetu UE ustalonym na lata 2014-2020, podobnie jak $\mathrm{w}$ okresie poprzednim, podstawowym mechanizmem stymulowania konkurencyjności w projektach europejskich były wytyczne. Tym razem, skonsolidowano zakres merytoryczny i zakres oddziaływania wytycznych, tworząc jeden zwarty akt administracyjny dla wszystkich funduszy w zakresie kwalifikowania wydatków: Wytyczne w zakresie kwalifikowalności wydatków w ramach Europejskiego Funduszu Rozwoju Regionalnego, Europejskiego Funduszu Spotecznego oraz Funduszu Spójności na lata $2014-2020^{50}$.

W nowym okresie programowania budżetu UE, duży nacisk położono na wyznaczenie linii demarkacyjnej pomiędzy sektorem publicznym i sektorem prywatnym, a w ślad za tym, stworzenie konstrukcji formalnoprawnych wyczerpująco regulujących kwestię wydatkowania środków publicznych w ramach projektów europejskich. Dookreślono Szczególne warunki realizacji zamówień publicznych udzielanych zgodnie z ustawa Pzp ${ }^{51}$ oraz Szcze-

u.p.p.p.s. Minister właściwy ds. rozwoju regionalnego poprzez delegację ustawową, zyskał uprawnienie do wydawania rozporządzenia w zakresie ustalania korekt finansowych, zob. obwieszczenie Ministra Inwestycji i Rozwoju z dnia 20 kwietnia 2018 r. w sprawie ogłoszenia jednolitego tekstu rozporządzenia Ministra rozwoju w sprawie warunków obniżania wartości korekt finansowych oraz wydatków poniesionych nieprawidłowo związanych z udzielaniem zamówień, Dz. U. z 2018 r. poz. 971 z załącznikiem (tzw. „taryfikatorem korekt finansowych").

50 Ministerstwo Infrastruktury i Rozwoju, Umowa Partnerstwa 2014-2020. Wytyczne w zakresie kwalifikowalności wydatków w ramach Europejskiego Funduszu Rozwoju Regionalnego, Europejskiego Funduszu Społecznego oraz Funduszu Spójności na lata 2014-2020, Warszawa, 10 kwietnia 2015 r., MIiR/H 2014-2020/12(01)/04/2015, https://www.funduszeeuropejskie.gov.pl/media/2155/Wytyczne_kwalifikowalnosc_wydatkow_EFFR_ EFS_FS_2014_20.pdf [dostęp: 11.07.2019 r.] (dalej: wytyczne w zakresie kwalifikowania wydatków EFRR, EFS, FS - wersja obowiązująca od 10.04.2015 r. do 13.10.2016 r.).

51 Rozdz. 6 podrozdz. 6.5.2 wytycznych w zakresie kwalifikowania wydatków EFRR, EFS, FS - wersja obowiązująca od 10.04.2015 r. do 13.10.2016 r. 
gólne warunki realizacji zamówień publicznych udzielanych zgodnie z zasada konkurencyjności $i^{52}$. Wyraźnie rozbudowano siatkę pojęciową, tworząc pojęcia administracyjnoprawne na potrzeby wytycznych, które znamy z innych aktów prawnych, jak: „zamówienie publiczne” określając jako:

[...] pisemną umowę odpłatną, zawartą pomiędzy zamawiającym a wykonawcą, której przedmiotem są usługi, dostawy lub roboty budowlane przewidziane $\mathrm{w}$ projekcie realizowanym $\mathrm{w}$ ramach $\mathrm{PO}$, przy czym dotyczy to zarówno umów o udzielenie zamówień zgodnie z ustawą Pzp jak i umów dotyczących zamówień udzielanych zgodnie z zasadą konkurencyjności $[\ldots]^{53}$.

Z tego wynika, że zakres przedmiotowy pojęcia, jest szerszy niż jego macierzysta wykładnia z u.p.z.p.: „umowa odpłatna zawierana pomiędzy zamawiającym a wykonawcą, której przedmiotem są usługi, dostawy lub roboty budowlane" ${ }^{\prime 54}$. Niepotrzebnie odnoszono się - mowa o wytycznych - do pisemności umowy, abstrahując już od wady literalnego sformułowania tej konstrukcji. Oznaczenie formy czynności prawnej, jaka winna być zachowana przy zawieraniu umów w ramach wydatkowania środków pieniężnych poprzez projekty europejskie, powinna regulować treść samej umowy o dofinansowanie projektu. Per analogiam, można było - ceteris paribus - uczynić podobnie jak ustawodawca, który redagując przepisy o zamówieniach publicznych, pozostawił kwestię formy czynności prawnej umowy w ramach aktu prawnego, który regulował je wyczerpująco w innym miejscu - u.f.p. Dodatkowo podmiotom gospodarczym realizującym wydatek $\mathrm{w}$ ramach zasady konkurencyjności, organ przyznał atrybut zamawiającego, gdy już np. przy rozeznaniu rynku brak odesłań w tym zakresie.

Ciekawym przykładem zaplątania się terminologicznego, poprzez twórczą działalność administracji publicznej jest zrównanie „umowy o dofinansowanie" (sfera prywatnoprawna) z "decyzją administracyjną" (sfera publicznoprawna) ${ }^{55}$, tworząc w zasadzie nie znaną w polskim pra-

${ }^{52}$ Rozdz. 6 podrozdz. 6.5 .3 wytycznych w zakresie kwalifikowania wydatków EFRR, EFS, FS - wersja obowiązująca od 10.04.2015 r. do 13.10.2016 r.

53 Rozdz. 3 pkt 1 lit. 11 wytycznych w zakresie kwalifikowania wydatków EFRR, EFS, FS - wersja obowiązująca od 10.04.2015 r. do 13.10.2016 r.

${ }_{54}$ Obwieszczenie Marszałka Sejmu Rzeczypospolitej Polskiej z dnia 3 października 2018 r. w sprawie ogłoszenia jednolitego tekstu ustawy - Prawo zamówień publicznych, Dz. U. z 2018 r. poz. 1986 z późn. zm.

55 Rozdz. 3 pkt 1 lit. aa wytycznych w zakresie kwalifikowania wydatków EFRR, EFS, FS - wersja obowiązująca od 10.04.2015 r. do 13.10.2016 r. 
wie administracyjnym - a postulowaną $\mathrm{w}$ doktrynie od lat - umowę administracyjną. Ale to tylko tytułem przykładu, do czego może nas zaprowadzić multiplikacja pojęć i tworzenie prawa ad hoc, przez nie do końca merytorycznie przygotowany do tego ośrodek.

Wracając do meritum, w ramach nowych wytycznych, nie tylko stworzono szczegółowe warunki realizacji zamówień publicznych, ale swoiste zasady ogólne: Ogólne warunki realizacji zamówień publicznych ${ }^{56}$. Określono m.in. przesłanki dla zamówień tego samego rodzaju, które w systemie zamówień publicznych utrzymują do dziś status rekomendacji. Ponadto wprowadzono ogólne przepisy dla terminów składania ofert (7 i 14 dni kalendarzowych), warunków udziału w postępowaniu i kryteriów oceny ofert, które były odpowiedzią na pojawiające się podczas kontroli, liczne naruszenia zasad przyznania dotacji - wzorując się notabene na u.p.z.p. Warto $\mathrm{w}$ tym miejscu zaznaczyć, że $\mathrm{w}$ prawie projektów europejskich kontrola łączona jest często z nadzorem, albowiem w "funkcji nadzoru tkwi element opieki i wspierania podmiotów poddanych nadzorowi" ${ }^{57}$. Niejednokrotnie organ kontrolny w zaleceniach pokontrolnych ${ }^{58}$, umożliwia podmiotowi kontrolowanemu przeprowadzenie postępowania naprawczego, pod groźbą sankcji - korekty finansowej. Dzieje się tak o ile oczywiście, można konwalidować sytuację prawno-faktyczną, a skala naruszenia warunków przyznania dotacji nie nosi znamion rażącego naruszenia przepisów prawa.

W porównaniu do ostatnich wydanych w ramach PO KL wytycznych w zakresie kwalifikowalności wydatków ${ }^{59}$, wyraźnie rozbudowano konstrukcję formalnoprawną zasady konkurencyjności. Po pierwsze, zmienił się próg bagatelności w systemie zamówień publicznych z 14 tys. euro na 30 tys. euro. Zrezygnowano z podawania w wytycznych kwoty bagatelności, odsyłając w tym zakresie do art. 4 pkt 8 u.p.z.p. ${ }^{60}$ Jednocześ-

56 Rozdz. 6 podrozdz. 6.5.1 wytycznych w zakresie kwalifikowania wydatków EFRR, EFS, FS - wersja obowiązująca od 10.04.2015 r. do 13.10.2016 r.

57 E. Przeszło, Kontrola udzielania zamówień publicznych, Poznań 2013, s. 121.

58 Sposób rozwiązania problemu napotkanego w trakcie kontroli rekomendowany przez organ kontrolny. Zalecenia pokontrolne stanowią część informacji pokontrolnej, o której mowa w art. 25 ust. 1 u.p.p.p.s.

59 Wytyczne w zakresie kwalifikowania wydatków w ramach PO KL - wersja obowiązująca od 01.05.2014 r.

60 Zob. rozdz. 6 podrozdz. 6.5 .3 pkt 1 lit. a wytycznych w zakresie kwalifikowania wydatków EFRR, EFS, FS - wersja obowiązująca od 10.04.2015 r. do 13.10.2016 r. 
nie naczelny organ administracji państwowej wykazał się nadmiernym paternalizmem ustalając przesłankę stosowania zasady konkurencyjności od sztywnej kwoty 50 tys. zł ${ }^{61}$. Rozbudowano treść zamówienia w fazie ex ante ${ }^{62}$. Pozostawiono nakaz publikacji ogłoszenia o wszczęciu postępowania w krajowym publikatorze ${ }^{63}$. Nieznacznie zmieniono zasady protokołowania przebiegu zamówienia. Konwalidowano niefortunny zapis ze słownika wytycznych w zakresie zawierania umów wynikający z zasady konkurencyjności, wyraźnie wskazując na formę pisemną. Określono zasady dokonywania zmian postanowień zawartej umowy oraz zamówień dodatkowych i uzupełniających. Co do zasady nie zmienił się trzon zasady konkurencyjności, wyrastający z pierwotnej koncepcji przesyłania jej treści do co najmniej trzech potencjalnych wykonawców.

Jeśli idzie o „rozeznanie rynku”, sama konstrukcja prawna w pierwszej wersji wytycznych straciła nieco na znaczeniu. Poświęcono jej znacznie mniej miejsca niż w poprzednich wytycznych - nie stanowiła nawet odrębnej jednostki redakcyjnej. Zakres jej stosowania uległ zmianie: "wydatki o wartości od 20 tys. PLN netto do 50 tys." 64 Zmiana in plus w porównaniu do Wytycznych w zakresie kwalifikowania wydatków w ramach $P O K L$, to obowiązek upublicznienia ogłoszenia o zamówieniu:

obowiązek dokonania i udokumentowania rozeznania rynku co najmniej poprzez upublicznienie zapytania ofertowego na stronie internetowej beneficjenta lub innej powszechnie dostępnej stronie przeznaczonej do umieszczania zapytań ofertowych w celu wybrania najkorzystniejszej oferty ${ }^{65}$.

Zmianą in minus jest decentralizacja uprawnień do wydawania szczegółowych procedur wydatkowych:

IZ PO może określić $\mathrm{w}$ wytycznych programowych lub umowie o dofinansowanie szczegółowe warunki i procedury potwierdzania przez beneficjenta, że

${ }^{61}$ Zob. rozdz. 6 podrozdz. 6.2 pkt 5 wytycznych w zakresie kwalifikowania wydatków EFRR, EFS, FS - wersja obowiązująca od 10.04.2015 r. do 13.10.2016 r.

62 Zob. rozdz. 6 podrozdz. 6.5 .3 pkt 5 lit. a tiret i-viii wytycznych w zakresie kwalifikowania wydatków EFRR, EFS, FS - wersja obowiązująca od 10.04.2015 r. do 13.10.2016 r.

63 Baza Konkurencyjności. Fundusze Europejskie, https://bazakonkurencyjnosci. funduszeeuropejskie.gov.pl/ [dostęp: 10.12.2017 r.].

64 Rozdz. 6 podrozdz. 6.2 pkt 4 wytycznych w zakresie kwalifikowania wydatków EFRR, EFS, FS - wersja obowiązująca od 10.04.2015 r. do 13.10.2016 r.

65 Rozdz. 6 podrozdz. 6.2 pkt 4 wytycznych w zakresie kwalifikowania wydatków EFRR, EFS, FS - wersja obowiązująca od 10.04.2015 r. do 13.10.2016 r. 
wydatek został dokonany w sposób racjonalny, efektywny i przejrzysty, z zachowaniem zasad uzyskiwania najlepszych efektów z danych nakładów ${ }^{66}$.

W aktualnej wersji Wytycznych w zakresie kwalifikowania wydatków EFRR, EFS, FS z 19 lipca 2017 r. ${ }^{67}$ mając na uwadze przejrzystość postępowania wydatkowego, stworzono wreszcie samodzielną jednostkę redakcyjną traktującą wyłącznie o instytucji „rozeznania rynku”. Nowy wkład w rozwój tego rodzaju mechanizmu stymulowania konkurencyjności $\mathrm{w}$ projektach europejskich, to określenie zachowania podmiotu w sytuacji, często spotykanej w praktyce - braku zainteresowania ofertą składaną przez zamawiającego:

w przypadku, gdy w wyniku upublicznienia zapytania ofertowego lub skierowania zapytania do potencjalnych wykonawców nie otrzymano ofert, niezbędne jest przedstawienie np. wydruków stron internetowych [...] z opisem towaru/usługi i ceną lub wydruków maili [...] z informacją na temat ceny za określony towar/ usługę, albo innego dokumentu $[\ldots]^{68}$.

\section{Zakończenie}

Oceniając publicznoprawne mechanizmy stymulowania konkurencyjności w projektach europejskich, w pierwszej kolejności, podkreślić należy wagę wykorzystania mechanizmu rynkowego. Chociaż forma zgłaszania popytu odbywa się na zasadach ustalonych przez naczelny organ administracji państwowej, ostatecznie to rynek, a właściwie konkurujące na nim podmioty, decydują o poziomie efektywności i w konsekwen-

${ }^{66}$ Rozdz. 6 podrozdz. 6.2 pkt 5 wytycznych w zakresie kwalifikowania wydatków EFRR, EFS, FS - wersja obowiązująca od 10.04.2015 r. do 13.10.2016 r.

67 Ministerstwo Rozwoju, Umowa Partnerstwa 2014-2020. Wytyczne w zakresie kwalifikowalności wydatków w ramach Europejskiego Funduszu Rozwoju Regionalnego, Europejskiego Funduszu Społecznego oraz Funduszu Spójności na lata 2014-2020, Warszawa, 19 lipca 2017 r., MR/H 2014-2020/23(3)07/2017, https://www.funduszeeuropejskie.gov.pl/media/42886/Wytyczne_w_zakresie_kwalifikowalnosci_19.pdf [dostęp: 11.07.2019 r.] (dalej: wytyczne w zakresie kwalifikowania wydatków EFRR, EFS, FS - wersja obowiązująca od 23.08.2017 r.).

68 Rozdz. 6 podrozdz. 6.5.1 pkt 2, wytycznych w zakresie kwalifikowania wydatków EFRR, EFS, FS - wersja obowiązująca od 23.08.2017 r. 
cji racjonalności poniesionego wydatku. Im wyższy stopień konkurencji na rynku, im mniejsza bariera wyjścia na ten rynek, tym wybrana oferta jest korzystniejsza ekonomicznie, a wydatek efektywniejszy ${ }^{69}$. Osobnym zagadnieniem badawczym, już nie stricte prawnym, jest sprawa administracyjnie stymulowanego popytu generowanego przez pomoc unijną i konsekwencje z tym związane dla rynków, na które wchodzi zamawiający-beneficjent.

„Rozeznanie rynku” i „zasada konkurencyjności”, dwa publicznoprawne mechanizmy stymulowania konkurencyjności w projektach europejskich, jak się zdaje, zostały stworzone z dwóch powodów, w celu:

- odformalizowania postępowania - stworzenia zamkniętej, prostej mikro-procedury wydatkowej, której złożoność uzależniona jest bagatelnością wydatku,

- stymulowania konkurencyjności - wprowadzenia mechanizmu zmuszającego beneficjentów do urynkowienia wydatków w ramach projektów europejskich.

Podstawowym miernikiem konkurencyjności w postępowaniach ofertowych jest liczba składanych ofert. Stanowi ona o stopniu konkurencyjności i poziomie zainteresowania rynkiem, w konsekwencji decydując o efektywności postępowania ofertowego i racjonalności wydatku; lecz tutaj brak wymiernych danych. Zresztą dla analizy dogmatyczno-prawnej nie są one niezbędne. Wiadomo za to, że „brak konkurencji [...] przekłada się na brak efektywności dokonywanych wydatków przez podmioty sektora finansów publicznych"70.

Warto podkreślić jeszcze jedną rzecz: beneficjenci wydatkują środki publiczne w ramach zatwierdzonego uprzednio budżetu wniosku o dofinansowanie projektu europejskiego. Zatwierdzenia dokonuje instytucja, w której złożono wniosek. Z tego wynika, że budżet projektu przed podpisaniem umowy o dofinansowanie, przeszedł już pozytywnie analizę ekonomiczno-techniczną, a procedura właściwa dla „rozeznania rynku” czy „zasady konkurencyjności” ma potwierdzić trafność przyjętej tam wyceny (założeń). Budżet projektu europejskiego jest „sercem”

69 Tę prostą "zasadę efektywności”, jako pierwszy zauważył Adam Smith. W swym teoremacie wyraźnie sugeruje, że mechanizm rynkowy ujawni się $\mathrm{w}$ pełni tylko przy doskonałej konkurencji, zob. A. Smith, Badania nad natura i przyczynami bogactwa narodów, t. 1, 2, przekł. A. Prejbisz, B. Jasińska, Warszawa 2007.

70 A. Panasiuk, Prawno-ekonomiczne aspekty systemu zamówień publicznych wpływajacych na ograniczenie swobody konkurowania, Warszawa 2005, s. 175. 
projektu. Żaden wydatek nieprzewidziany uprzednio $\mathrm{w}$ budżecie, nie może zostać poniesiony. Wydatki w budżecie projektu mają charakter planistyczny - są zaplanowane i ponoszone zgodnie $\mathrm{z}$ harmonogramem wniosku o dofinansowanie projektu. Wydatki na zamówienia tożsame przedmiotowo i rodzajowo są grupowane i sumowane z punktu widzenia trwania całego projektu, a nie w systemie np. rocznym; już ta zasada w dużym stopniu decyduje o ich racjonalności. Tak więc pole do nadużyć jest ograniczone.

Postulaty odformalizowania postępowania w zakresie wydatkowania funduszy w ramach projektów europejskich, można porównać do ogólnych postulatów uproszczenia prawa - $\mathrm{w}$ tym wypadku uproszczenia w zakresie prawa procesowego. Jak słusznie wskazuje R. Blicharz: „niejednokrotnie jest to wynikiem nie tyle nieudolności ustawodawcy [organu administracji publicznej - M.K.] co sukcesywnie postępującej złożoności zjawisk społecznych i ekonomicznych"71. Tak samo przy określaniu publicznoprawnych mechanizmów stymulowania konkurencyjności w projektach europejskich, organ administracji tylko reagował i reaguje na zmieniające się czynniki zewnętrzne i wewnętrzne, pozostając zazwyczaj krok za praktyką.

Słowa kluczowe: projekty europejskie, kwalifikowanie wydatków, administracyjnie stymulowana konkurencyjność, akt administracyjny generalny, zamówienia publiczne

\section{Bibliografia}

Adamiecki K., Nauka organizacji i jej rola w życiu gospodarczym, Warszawa 1932.

Blicharz R., Instytucje prawa rynku kapitałowego, Toruń 2013.

Boć J. (red.), Prawo administracyjne, Wrocław 2007.

Chróścielewski J., Akt administracyjny generalny, Łódź 1994.

Karpińska K. [w:] T. Lubińska (red.), Budżet zadaniowy w Polsce. Reorientacja z wydatkowania na zarzadzanie pieniędzmi publicznymi, Warszawa 2007, s. 39-42.

Kiełkowski T., Sprawa administracyjna, Kraków 2004.

Knosala E., L. Zacharko, A. Matan, Elementy nauki administracji, [Wrocław] 2002.

71 R. Blicharz, Instytucje prawa rynku kapitałowego, Torun 2013, s. 9. 
Pakuła A. [w:] A. Chrisidu-Budnik, J. Korczak, A. Pakuła, J. Supernat, Nauka organizacji i zarzadzania, [Wrocław] 2005, s. 313.

Panasiuk A., Prawno-ekonomiczne aspekty systemu zamówień publicznych wpływające na ograniczenie swobody konkurowania, Warszawa 2005.

Politaj A. [w:] M. Brol (red.), Zarys ekonomii sektora publicznego, Wrocław 2010, s. 191-205.

Przeszło E., Kontrola udzielania zamówień publicznych, Poznań 2013.

Smith A., Badania nad natura i przyczynami bogactwa narodów, t. 1, 2, przekł. A. Prejbisz, B. Jasińska, Warszawa 2007.

Stankiewicz J. [w:] E. Ruśkowski (red.), System prawa finansowego, t. 2. Prawo finansowe sektora finansów publicznych, Warszawa 2010, s. 270-271.

Stiglitz J.E., Ekonomia sektora publicznego, przekł. R. Rapacki i in., Warszawa 2004.

Wernik A., Finanse publiczne. Cele, struktury, uwarunkowania, Warszawa 2011.

Wierzbowski M., A. Wiktorowska [w:] M. Wierzbowski, J. Jagielski , J. Lang, M. Szubiakowski, A. Wiktorowska (red.), Prawo administracyjne, Warszawa $2008^{8}$, s. 277.

\section{PUBLIC-LAW MECHANISMS OF STIMULATING COMPETITION IN EUROPEAN PROJECTS}

\section{Su m m a ry}

The Republic of Poland has been able to absorb external sources of financing of various degrees of destination since the accession of Poland to the European Union (EU). The extra inflow of capital has dynamized the development of markets in Poland, including the public procurement segment. It has become necessary to create and then modify a mechanism of stimulating competition while spending money transfers from the EU budget in response to changes of exogenous and endogenous factors. The aim of the article is to show the genesis, evolution and preliminary assessment of the mechanisms of stimulating competition in European projects. The work consists both theoretical remarks and those related to the practice of functioning of the laws in selected areas of the economy. The subject of the analysis are the beneficiaries of funds from the European Social Fund (mainly the private sector). The object of the analysis are legal and administrative norms, related to making public purchases in frame of European projects.

Key words: European project, qualification of expenditure, administratively stimulated competition, general administrative act, public procurement 


\section{ПУБЛИЧНО-ПРАВОВЫЕ МЕХАНИЗМЫ СТИМУЛИРОВАНИЯ КОНКУРЕНЦИИ В ЕВРОПЕЙСКИХ ПРОЕКТАХ}

\section{Резюме}

С вступлением Польши в структуры Европейского Союза (ЕС) наша страна открыла возможность поглощения внешних источников финансирования различной степени назначения. Дополнительный приток капитала ускорил развитие рынков в Польше, включая сегмент государственных закупок. Было необходимо создать, а затем изменить, в ответ на изменение экзо- и эндогенных факторов, механизм стимулирования конкуренции при расходах денежных переводов из бюджета ЕС. Цель работы - показать генезис, эволюцию и предварительную оценку механизмов стимулирования конкуренции в европейских проектах. Содержание работы состоит из теоретических и правовых замечаний, а также тех, которые касаются практики функционирования рассмотренных правовых норм в отдельных областях экономики. Предметом анализа являются бенефициары средств Европейского социального фонда (в основном, частный сектор). С другой стороны, предметом анализа является набор правовых и административных стандартов, связанных с осуществлением государственных закупок в рамках европейских проектов, определенных государством.

Ключевые слова: европейские проекты, приемлемость расходов, административно стимулируемая конкуренция, общий административный акт, государственные закупки 